\title{
Japan and Asian Values: A Challenge for Japan's East Asian Policy in the New Century
}

\author{
by Fumitaka Furuoka, Beatrice Lim Fui Yee and Roslinah Mahmud \\ J. Contemp. East. Asia (ISSN 2383-9449) Vol. 5, No. 1, September 2006: 1-8 \\ DOI: http://dx.doi.org/10.17477/jcea.2006.5.1.001 \\ (eastasia.at ISSN 1684-629X)
}

Since its defeat in the Second World War, Japan has been fostering good ties with Western countries, especially the United States. However, some East Asian leaders emboldened by their countries' economic success have proclaimed that the future belongs to Asia and have put forward the "Asian values" argument. It is interesting to note that some elements of the "Asian values" argument resemble ultranationalist discourse that was dominant in Japan before the war. The Japanese Government had a great opportunity to reappraise its role in international politics and take stock of its economic and diplomatic relations with East Asian countries after the end of the Cold War. To meet future challenges, Japan should fully overcome anti-Western sentiment and participate in establishing a truly democratic East Asian regionalism based on the "universal values" of human rights, democracy and freedom. This may prove to be one of the biggest challenges for Japan's East Asia policy in the new century.

\section{Introduction}

After the Meiji Restoration (1868), Japan re-established diplomatic relations with Western countries. Under a slogan "Rich Economy and Strong Army (FukokuKyohei)", Japan began to modernize its economic mechanism and strengthen its military power. At the same time, in order to catch up with advanced countries, Japan began creating the "first" East Asian regionalism under name of the "Co-prosperity Sphere (Kyoeiken)" and subjugating its East Asian neighbours through the use of military force (Furuoka, 2005).[1]

Japan's attempt to catch up with Western countries was interrupted by a self-destructive war that Japan waged against the Allies. Japan lost the war and in 1945 declared its unconditional surrender to the Allies. After the war, the Japanese Government's top priority was rehabilitating the country's economy. For this, all available resources were invested into several key industries that produced exportable manufactures and brought in much needed foreign currency revenues.

It took decades for Japan to restore its economy. In the process, the country shed its confrontational anti-Western stance. Furthermore, Japan renounced the use of military power in international disputes by promulgating the "peace constitution (heiwa-kenpo)". The Japan-US security pact gave Japan an opportunity to concentrate on the pursuit of its own economic interests. More important, the huge US market has been vital for Japan's export-related industries.[2] In order to bolster its increasing economic power, Japan embarked on creating a production network in East Asia, which, in effect, could be regarded as the "second" attempt to create East Asian regionalism (Furuoka, 2005).

In pre-war Japan, strong anti-Western sentiment was all pervading. Japan's excessive nationalism was accompanied by an openly confrontational attitude toward the West. There were voices of dissent though as some Japanese intellectuals maintained that Japan should go along with the international order that had been established and maintained by Western countries. But this was the 
opinion of a negligible minority.

Nowadays, despite apparently friendly and smooth relations between East Asian and Western countries, anti-Western sentiment is still ingrained into the political thinking of a part of the East Asian political elite. Anti-Western feelings resurfaced during the heyday of the region's economic boom in the form of the "Asian values" discourse. Though the "Asian values" argument did not enjoy uniform support among East Asian political and intellectual elites who could find no distinction between the "Asian" and "Western" set of values, they were overwhelmed by more outspoken proponents of "Asian values".

The main objective of this paper is to examine the striking similarities between the line of reasoning employed by the proponents of "Asian Values" and the argumentation of the pre-war Japanese ultra-nationalist ideologues. This paper analyses an emerging new paradigm of East Asian political thought - "Neo-Asian Values". It also explores Japan's diplomatic strategies to play an active role in order to create a truly democratic East Asian regionalism which would be based on the "universal values" of human rights, democracy and freedom. This paper consists five sections. Following the introduction, the second section analyses the similarities between "Asian values" and Japan's pre-war ultra-nationalism. The next section discusses an emerging new political paradigm in East Asia - "Neo-Asian values". The fourth section examines a challenge for Japan's East Asian policy. The final section is the conclusion.

\section{Japan and Asian Values}

Undeniably, anti-Western sentiments in pre-war Japan and in modern East Asia differ in scale and scope. In Japan, strong anti-Western feelings had been translated into a militarist policy that led Japan to a self-destructive war. The present-day "Asian values" discourse is mainly employed as a tool to gain political support and endorsement from the domestic audiences and, thus far, remains pure rhetoric.

However, there are striking similarities between the line of reasoning employed by the proponents of "Asian Values" and the argumentation of the pre-war Japanese ultra-nationalist ideologues.

The following four similarities attract particular attention: 1) assertion of the uniqueness of Asian culture, 2) claims of the cultural decay and imminent economic decline of the West, 3) accusations of the West's interference into domestic policies of other countries, 4) allegations of the hypocrisy of the West.[3] Each of these four contentions is briefly reviewed below.[4]

\subsection{Uniqueness of Asian Culture}

Before the Second World War, Japanese ultra-nationalists stressed Japan's "uniqueness" while they put Western ideals and norms under harsh criticism. A booklet entitled "Kokutai no Hongi (Our National Policy)" published by the Ministry of Education in 1937 may serve as an example of the all-pervading nationalist discourse. The brochure emphasized distinctive characteristics of Japanese society, culture and history and maintained that an alien value - individualism - was at the root of ideological and social confusion in Japan. The booklet also offered a general critique of Western philosophy and suggested that Japan's mission was to create a new amalgam of Eastern and Western thought (Tsunoda et al. 1958: 285).

In the 1990s, leaders of some East Asian countries began to talk about "Asia's own" values juxtaposing them with "alien" ideals, such as democracy, human rights and freedom. Furthermore, at the Asian Regional Meeting on Human Rights in Bangkok in 1993, delegates came up with their own definition of human rights. Though the Bangkok Declaration, signed by over 40 countries, did not outright reject the universality of human rights, it suggested that the issue should be considered in the context of a dynamic and evolving process of international norm-setting, bearing in 
mind the significance of national and regional particularities and various historical, cultural and religious backgrounds (Fairclough 1993: 21).

\subsection{Decline of the West}

Predictions of the decline and eventual demise of Western culture and civilisation enjoyed much popularity among Japanese ultra-nationalists in pre-war Japan. In 1937, Japanese scholar Masaru Nakayama wrote:

It goes without saying that the cultures of Europe are incapable of rescuing themselves any more, much less the world at large. The new potential power lies with a third civilization. It makes both Eastern and Western civilizations come alive with a harmonious combination... Japan may rightfully serve as a catalyst for this combination.

Nakayama saw Japan's mission as that of creating a "third civilisation". He also put forward an idea that Japan should form an economic block with its East Asian neighbours (Miwa 1995: 142).

In the end of the $20^{\text {th }}$ century Asia was the most rapidly developing region in the world. This gave rise to assertions that the future belongs to Asia. Some Asian political and opinion leaders asserted that although Western countries are powerful enough to dominate the global economy, there was no guarantee that they would be able to indefinitely maintain political and economic supremacy. As former Malaysian prime minister Mahathir Mohamad put it, "They (Western countries) can fail. ...And they can destroy themselves" (Lim 2000: 11).

\subsection{Western Interference}

Before the Second World War, the Japanese Government often accused Western countries of interference in internal affairs of other countries. Moreover, it used the argument to justify Japan's expansionist policies. When, in 1933, the Lytton Commission's report condemned Japanese occupation of Manchuria, the Japanese Government called it foreign interference and withdrew from the League of Nations. Ultra-nationalists in pre-war Japan described Japan's expansionist policy as "Asian Monroe Doctrine". They argued that while the US vied for a leading role in the Americas and put forward the Monroe Doctrine to achieve this aim, Japan's role in Asia was analogous. Using this line of argumentation, ultra-nationalists in pre-war Japan insisted that "American interference in Japan's Asian affairs was therefore unreasonable" (Kitaoka 1990: 173).

There are modern Asian leaders - among them Myanmar foreign minister Win Aung - who regard Western countries' scrutiny of their domestic policies as foreign interference. In 2000, U Win Aung pointed out that the non-interference in domestic affairs of a country is an indispensable principle underpinning the current international system and proceeded to say, "There are some who are bent on compromising these cardinal principles of international relations, voicing support for interference in countries' internal affairs on various grounds" (Aung 2002). Similar rhetoric was employed by former president of China Jiang Zemin. In his speech to the United Nations he maintained, "Some large countries frequently use the pretext of 'freedom', 'democracy' or 'human rights' to encroach upon the sovereignty of other states, interfering in their internal affairs" (Moody 1996: 166).

\section{4 Hypocrisy of the West}

Nationalists in pre-war Japan often talked about the hypocrisy of the West and the need to oppose Western domination. Before the Second World War, many among the Japanese intellectual and political elite were very critical of the Western countries' diplomatic policy. A young nationalist, Fumimaro Konoe, wrote in 1918, 
The pacifism of England and America represent the kind of peace-at-any price principle advocated by those who find it convenient to uphold the status quo, and has nothing to do with justice and humanism. Japan should espouse the overthrow of the status quo.

For Konoe, who presided over three cabinets before the Second World War and took his own life after Japan's defeat in the war, Western pacifism was nothing more than a hypocritical pose, a façade to conceal the injustice of the existing international order structured to benefit the West. Konoe's viewpoint reflected Japan's increasing nationalism and anti-Western stance during that period (Konoe 1995: 14).

More recently, the sincerity of Western human rights watchers has often been questioned by some East Asian leaders who accuse the West of being hypocritical. For example, Chinese officials maintain that it is hypocritical for the US administration to criticize other countries' human rights practices without improving the human rights condition in its own country. As a high-ranking Chinese Government officer asserted, "While launching a loud human rights crusade against other countries in the world, the United States is turning a blind eye to its own serious human rights violations. This only serves to prove the US hypocrisy in its so-called concern for human rights" (Qiao 2001).

\section{Neo-Asian Values}

Though the current leaders of East Asian countries have not shown outright hostility toward the West, as had been the case with the Japanese ultra-nationalists during the war, there remain political and opinion leaders in East Asia who do not recognize human rights and democracy as universal values and question the merits of freedom.

Those leaders assert the cultural superiority of Asia over the West. Given that anti-Western sentiment still lingers in the region, one of the biggest challenges for future East Asian integration could be finding a way in which the region, while maintaining its own cultural identity and acknowledging the existing differences with the West, will be able to establish an open type of regional grouping that would allow it to harmoniously and peacefully co-exist with the rest of the world.

At this junction, there is an encouraging trend among East Asian political and opinion leaders to recognize democracy, human rights and freedom as "universal values" and not regard them as alien to Asian culture elements. This progressive political thinking in East Asia could be viewed as "neo-Asian values". For instance, Philippine president Gloria Macapagal-Arroyo does not share the viewpoint that concern for human rights is irrelevant in Asia. She maintains, "Minister Ramos Horta once said that democracy and human rights are not an invention of the West. We wholeheartedly agree" (Macapagal-Arroyo 2002).

Moreover, former South Korean president Kim Dae Jung dismisses the notion that democracy is not suitable for Asian countries' political system. In his opinion, such arguments serve to justify authoritarian regimes and state-led economies in some Asian countries (Asahi Shimbun, 9 October 1998).

Former Taiwanese president Lee Teng Hui maintains that there should be no differences in the approach to universal values such as human rights and democracy. Lee asserts that the "Asian values" argument was put forward by political leaders seeking a way to justify authoritarian regimes in their countries (Sankei Shimbun, 28 January 1998).

A wide range of Non-Governmental Organisations (NGOs) in Asian countries also express their full support for the universality of human rights and democracy. The Bangkok NGO Declaration (1993) dismisses appeals to cultural relativism as an effort to justify deviations from international norms and maintains that human rights 
are universal and rooted in different cultures. The Declaration supports cultural pluralism and condemns cultural practices that derogate universally accepted human rights. Furthermore, it does not regard the advocacy of human rights as an encroachment upon national sovereignty.

\section{New Strategies for Japan's Asia Policy}

The end of the Cold War rendered the conceptual meaning of "the West" ambiguous. The threat of communism that had for a long time cemented Japan's relations with the West dissipated and there remained no guarantee that Japan would always go along with Western countries' policies, especially US policies, in the future. Samuel P. Huntington observed that with the end of the Cold War, relations between Japan and the United States have grown increasingly difficult and cultural differences have begun to aggravate economic conflict. As he commented, "Here cultural difference exacerbates economic conflict" (Huntington 1993: 34).

Despite the fact that the US and Japan play complimentary roles in the international political arena, apparently the two countries do not subscribe to the same set of values and norms and do not entirely agree with each other's foreign policies. For instance, in the 1990s, the US Government extensively used economic sanctions as a means to promote "universal values", such as human rights, democracy and freedom. Japan, on the other hand, despite the Japanese Government's pledge to use the country's aid power to promote the above values, has yet to show its commitment to the cause. Moreover, Japan has been criticised for its ambivalent attitude toward the issues of human rights and democracy (Arase 1993).

The end to the ideological conflict between Western democracies and the Communist camp may help create an international environment where Japan is able to enjoy more autonomy to reinforce its relations with other Asian countries. As Tamamoto (1991: 579) notes, "Just as the Cold War divided Germany, it separated Japan and Asia. Now the end of the Cold War, coupled with Japan's paramount economic position in Asia, is pushing Tokyo toward assuming a much greater political role in the region."

Japan and its Asian neighbours have similar socio-cultural traditions and share common religious heritage. All of this may prove to be conducive to forging stronger ties between the countries of the region. This possibility has been suggested and commented upon before. As Ivan Hall put it, "Those in the West who attend to geo-cultural matters have long predicted the 'return' of Japan to its 'Asian roots', and we now find the Japanese themselves proclaiming 'Re-Asianisation' of their country" (Hall 1994/1995: 19).

Since the end of the Cold War, the Japanese Government has had a good opportunity to reappraise its role in international politics and take stock of its economic and diplomatic relations with East Asian countries. In this new century, East Asian countries have started working very hard to create a new East Asian regionalism. For example, their political leaders in the region held a regional summit in Kuala Lumpur, Malaysia in December 2005.

On the one hand, there could a danger that conventional wisdom of "Asian values" might hijack the new East Asian regionalism. This type of regional grouping might face some difficulty in co-existing with other regional grouping. On the other hand, there could be a hope that new regional grouping would overcome anti-Western rhetoric and would be established as truly democratic East Asian regionalism.

If the encouraging trend of "Neo-Asian values" could prevail in the region, this could help to create a better climate for the formation of new East Asian regionalism, where all member countries uphold the principles of democracy and freedom, and share respect for human rights. Adherence to these values could become instrumental in overcoming the conventional "patron-client" relationship pattern that was formed in previous East Asian regionalism (Furuoka, 2005). More important, recognizing and upholding "universal values" could pave the way for peaceful 
co-existence and wider co-operation with economic and political groupings in other regions.

Japan may want to consider the following three diplomatic strategies to retain a place in future East Asian integration. Firstly, Japan could contribute to dissipating the still lingering anti-Western sentiment in the region. For this, ultra-nationalist sentiment must first be checked within Japan's own borders.

Secondly, the Japanese Government may wish to be more active in promoting the "universal values" of democracy, freedom and human rights in East Asia. By supporting progressive political thinking, or "neo-Asian values", Japan could contribute to the emergence of a truly democratic East Asia.

Finally, Japan could continue nurturing good diplomatic relations with both Western countries and its Asian neighbours. By doing so, Japan may be able to assume a mediator's role between East Asia and the West, especially the United States, should any conflict or friction arise between the two regions.

\section{Conclusion}

Japan made the "first" attempt to lead neighbouring Asian countries before the Second World War. At that time, Japan was imposing its own ideals and values. After the Second World War, Japan fully concentrated on restoring its war-torn economy. In order to catch up with the Western countries, Japan embarked on creating the "second" East Asian regionalism.

All the while, Japan has been fostering close ties with Western countries, especially the US. While Japan was nurturing good ties with the West, some East Asian leaders proclaimed Asia's cultural supremacy over the West and put forward the "Asian values" argument.

The Asian economic crisis of 1997 effectively put an end to the "Asian values" debate. Some elements of the "Asian values" argument that gained popularity during the heyday of the "East Asian Miracle" resembled Japan's ultra-nationalism that had been a dominant discourse during the war. The following four similarities particularly attract attention: 1) assertion of the uniqueness of Asian culture, 2) claims of the cultural decay and imminent economic decline of the West, 3) accusations of the West's interference into domestic policies of other countries, 4) allegations of the hypocrisy of the West.

Since the end of the Cold War, the Japanese Government has had a golden opportunity to reappraise its role in international politics and take stock of its economic and diplomatic relations with East Asian countries. To meet future challenges, Japan should fully overcome anti-Western sentiment and participate in establishing a new regional grouping that would be based on the "universal values" of human rights, democracy and freedom. This may prove to be one of the biggest challenges for Japan's East Asia policy.

\section{Notes}

11] The paper uses a broader definition of "East Asia" that includes Northeast Asia and Southeast Asia.

[2] Other East Asian countries followed Japan's example and exported their goods to the US. In other words, the vast US market has been a very important element for the region's economic development and the creation of a production network in East Asia.

[3] For a more detailed discussion on the classification of "Asian values" see Furuoka (2002) and Kuroyanagi (1995). 
became a part of the "Asian values" discourse. However, nothing in the pre-war Japanese ultranationalist rhetoric resembled this argument.

\section{References}

Arase, David. 1993. "Japanese Policy Toward Democracy and Human Rights in Asia." Asian Survey 33 (10): 935-952.

Aung, U Win. 2002. "Statement by His Excellency U Win Aung, Minister for Foreign Affairs of the Union of Myanmar, at the General Debate of the $55^{\text {th }}$ Session of the United Nations General Assembly". [accessed on 19 October 2002].

<http://www.Myanmar.com/Ministry?mofa/speeches/speech4.html >

Buzan, Barry. 1988. "Japan's Future: Old History Versus New Roles." International Affairs 64(4): 557-573.

Calder, Kent E. 1988. "Japanese Foreign Economic Policy Formation: Explaining the Reactive State." World Politics 40(4): 517-548.

Fairclough, Gordon. 1993. "Standing Firm.” Far Eastern Economic Review, 15 April 1993: 21

Furuoka, Fumitaka. 2002. "Challenges for Japanese Diplomacy After the End of the Cold War." Contemporary Southeast Asia 24(1): 68-81.

Furuoka, Fumitaka (2005) "Japan and the Flying Geese Patten of East Asian Integration”, eastasia.at (Online Journal of the Austrian Association of East Asian Studies), Vol.4, No.1.

Hall, Ivan P. 1994/1995. “Japan's Asia Card.” The National Interest 38: 19-27.

Huntington, Samuel P. 1993. "The Clash of Civilisations?" Foreign Affairs 72(3): 22-49.

Katada, Saori N. 2002. "Japan's Two-Track Aid Approach, The Forces Behind Competing Trends." Asian Survey 42(2): 320-342.

Kitaoka, Shin'ichi. 1990. "Prophet Without Honour: Kiyosawa Kiyoshi's View of Japanese-American Relation". In James W. White, Michio Umesaki and Thomas R.H. Havens (eds). The Ambivalence of Nationalism: Modern Japan Between East and West. Maryland: University Press of America, Inc. 1990: 157-183.

Konoe, Fumimaro. 1995. "Against a Pacifism Centred on England and America." Japan Echo 22 (Special Issue): 12-14.

Kuroyanagi, Yoneji. 1995. "Jinken Gaiko tai Eijian Uei [Human Rights Diplomacy and the Asian Way]." Kokusai Mondai 422: 31-45.

Lim, Kit Siang. 2000. "Malaysia's Foreign Rhetoric Anti-Budget." Office of Lim Kit Siang (Malaysia's Democratic Action Party Newsletter) 39: 11-19.

Macapagal-Arroyo, Gloria. 2002. "President Gloria Macapagal-Arroyo's Speech During the UNDP Global Launching of the Human Development Report 2002". [accessed on 23 August 2002] <www.ops.gov.ph/speeches2002/speech-2002July24.htm>

Mahathir, Mohamad. 1988. "New Government Policies." In K.S. Jomo (ed). Mahathir's Economic Policy. (Kuala Lumpur: Insan 1988). Pp. 1-3.

Miwa, Kimitada. 1990. "Japanese Polices and Concepts for a Regional Order in Asia, 1938-1940." In James W. White, Michio Umesaki and Thomas R.H. Havens (eds). The Ambivalence of Nationalism: Modern Japan Between East and West. Maryland: University Press of America, Inc. 1990: 133-156.

Miyashita, Akitoshi. 1999. "Gaiatsu and Japan's Foreign Aid. Rethinking the Reactive-Proactive Debate." International Studies Quarterly 43(4): 695-731.

Moody, Peter R. 1996. "Asian Values.” Journal of International Affairs 50(1): 166-192.

Pempel, T.J. 1996/1997. 'Gulliver in Lilliput: Japan and Asian Economic Regionalism.' World Policy Journal 13(4): 13-26.

Peng, Dajin. 2000. "The Changing Nature of East Asia as an Economic Region." Pacific Affairs 73(1): 
171-191.

Qiao, Zhonghuai. 2001. 'Statement by H.E. Ambassador Qiao Zhonghuai, Head of the Chinese Delegation, on Item 9 at the $57^{\text {th }}$ Session of the Commission on Human Rights.' [accessed on 19 October, 2002] <http://www.fmprc.gov.cn/eng/12270.html>

Tamamoto, Masaru. 1991. “Japan’s Uncertain Role.” World Policy Journal 8(4): 579-597.

Tay, Simon. 2001. "Looking Beyond the Yasukuni Shrine Issue." [accessed on 3 May 2002. $<$ http//www.asahi.com/English/asianet/column/eng_010921.html>

Tsunoda, Ryusaku, Wm Theodore de Bary and Donald Keene. 1958. Sources of Japanese Tradition. Volume II. New York: Columbia University Press 1958: 278-288.

Fumitaka Furuoka, Beatrice Lim Fui Yee and Roslinah Mahmudi are affiliated with the School of Business and Economics at the Universiti Malaysia Sabah.

E-mail: fumitaka [at] ums.edu.my 